\title{
Women's Reproductive Rights and Population Explosion
}

\author{
Shyam S Deepti
}

\begin{abstract}
The notion of population was discussed scientifically in 1994 at Cario during the international conference of Population and development where it was highlighted that not just poverty but lack of development is population explosion. During subsequent years the focus shifted to women's reproductive rights. Apart from physiological phenomenon, it was recognized that reproduction is also a social issue especially in developing world where around $40 \%$ pregnancies are unwanted. Hence we need to look at women empowerment from a broader perspective, from their right to education to have the freedom to choose work for being economically independent.

Reproductive right it its true sense is to have the control on their bodies which eventually translated into reproductive health.

To conclude action at various levels is required to address this issue.
\end{abstract}

Keywords: Empowerment, Fertility, Population, Women rights.

How to cite this article: Deepti SS. Women's Reproductive Rights and Population Explosion. Curr Trends Diagn Treat 2017;1(2):104-106.

\section{Source of support: Nil}

Conflict of interest: None

\section{INTRODUCTION}

Efforts to control the population can be traced back to history from two centuries when, in 1778, Thomas Robert Malthus pointed out the relation of population with the growing need of food and predicted misery of famine. His prediction did not come true due to advances in technology in the field of agriculture. ${ }^{1}$ From the last decade, the global population has increased 1.9 times, while food production has shown 2.6 times growth. He also pointed out that the poor class people produce more children without going into any reason and he simply suggested that they should limit their children according to their resources. Until date, the notion is that poor people are responsible for population explosion.

In 1994, the International Conference on Population \& Development for the first time highlighted the issue of

\section{Professor}

Department of Community Medicine, Government Medical College, Amritsar, Punjab, India

Corresponding Author: Shyam S Deepti, Professor Department of Community Medicine, Government Medical College, Amritsar, Punjab, India, e-mail: drdeeptiss@gmail.com population in relation to development. The conference of Cairo pointed out that the issue of adoption of the concept of Reproductive Rights and programs of relevant action included need for male responsibility along with women empowerment. $^{2}$

The concept of the World Health Organization (WHO) on Reproductive Rights rests on the recognition of the basic rights of all couples and individuals to decide freely and responsibly the number, spacing, and timing of their children, and to have the information and means to do so, and the right to attain the highest standards of sexual and reproductive health. It also includes the rights of all in making decisions concerning reproduction, free of discrimination, coercion, and violence. ${ }^{3}$

If we look into the evolutionary process of organisms in nature, we can observe that as the animal advances, the fertility automatically reduces. In primary mammals to the higher primates, the number of offspring production is relatively less. We are in this advanced category as human beings. It has also been observed that numbers of offspring are related with survival rate. This fact can be correlated with more number of children among the poor due to their uncertainty of survival, which was ignored by Mr Malthus. ${ }^{1}$

Fertility, as it is perceived and measured in terms of women physiology, is not the sole responsibility of women. Man is equally a partner in this process. While talking about the evolution of fertility, the biological aspects of the body are discussed mostly. There is one important and highly convincing issue, which is socially related in case of human beings. In 1995, the Fourth World Conference on women in Beijing in its nonbinding declaration and platform for action supported the Cairo Programme of Reproductive Health, but established a broader context as the human rights of women include their rights to have control over and decide freely on matters related to sexuality including sexual and reproductive health, free of coercion, discrimination and violence, equal relationship between men and women, along with full respect for the integrity of the person, and requiring mutual respect, concern, and shared responsibility for sexual behavior and its consequences. ${ }^{4}$

The social issue, which needs attention, is that how the body of a woman is regulated under social norms. In simple words, it can be understood that when she has no control over her body, she has no control over her fertility. The United Nations report says that out of the estimated 186 million pregnancies that occur in the developing 
world every year, about 75 million were unintended. On the contrary, all our efforts to control the population are pointed toward women, i.e., it may be development of contraceptives, medical termination of pregnancy, etc. ${ }^{5}$

One more important issue is the sexual behavior of human beings, which is not necessarily linked with reproduction. However, even in this behavior, women cannot take decisions regarding their own body. If she refuses for this act, men usually express that for what have I brought her? One expression was "बेठ ढित भै टिम सा भान्ण य'్ㄷㄷ जै" (What for! I am going to make pickle from her).

Women empowerment in a broader spectrum embraces aspects, such as right to education and the freedom to choose work for being economically independent. But, from the perspective of reproductive rights, it includes freedom to decide the age of marriage, when to have children, the number of children, etc. ${ }^{6,7}$

The Centre for Reproductive Rights has supported the broader vision for reproductive rights given by WHO to take an action at worldwide level and fight against the laws and policies which are hostile to women's health and rights. We need to engage in careful, thoughtful, and substantive discussions about the services necessary for women's wellbeing throughout their lives, as well as regarding comprehensive sex education in our schools, domestic violence resources, affordable and reliable contraception, fertility treatment, other pregnancy issues and also abortion services, prevention of forced sterilization, female genital mutilation, and other issues of concern.

The problem with the rigid patriarchal society like India is that women have been traditionally confined to their homes and their role has been limited. Male dominance is the sole reason for domestic violence in Indian society and one of the major reasons for domestic violence is denying sex. Wanting the male child in the family is another issue related with the patriarchal society. It is an obsession and the size of the family is not an issue to want for a son. It has been observed that when the a woman is working and economically empowered, the scope for wanting the son to complete the family is comparatively less. ${ }^{8}$

Female education is a first step toward empowering women to have control over her body. By that, we can say that making her conscious about reproductive rights is fundamental. The more empowered she feels, the greater is the freedom and options available to her relevant to these issues. Studies have suggested that one year of female schooling, particularly, secondary school reduces fertility by $10 \%$. Even with education, the population momentum can be checked by delaying the women's age at first birth and then spacing further births.

According to the United Nations Children's Fund, 15\% of girls in the rural area across the country are married before they are even 13 and $52 \%$ of girls have their first pregnancy between 15 and 19 years of age. ${ }^{7}$ The National Population Policy 2000 has emphasized on making school education compulsory and free up to 14 years of age and also has laid stress on reducing the dropout rates, as well as promoting the delay of marriage up to 18 years, if not 20 years of age. ${ }^{9}$ This is mainly of concern in rural areas where marriage is around 16 years of age. ${ }^{10}$

Gender gap in literacy is shrinking, which will improve the socioeconomic status of the family and will definitely reflect in reproductive health. ${ }^{11}$ There is an inverse relation between fertility and education status, with at the least high school education. ${ }^{9}$ The question of survival is also definitely related with education of women as she can care for the child in better ways and avail the health services available for children like immunization and nutrition supplementation.

Undoubtedly, quality health services are required so that reproductive health facilities can be accessed universally. But, we have also learned from experience that simply providing or strengthening health services may not necessarily lead to their utilization, particularly by poor women and the ones who are at risk. Given the scope and complexities of social, cultural, economic, and geographical factors, they are found influencing to a great extent one's health-seeking behavior. It is evident that not all these factors can be addressed appropriately through merely health system initiatives. Therefore, there is a requirement for a more expansive set of strategies and leadership at the community level to influence some norms and catalyze action.

The target of achieving universal access to reproductive health was added to the Millennium Development Goals in the year 2007. It included four specific indicators, i.e., adolescent birth rate, antenatal care visits, contraceptive prevalence, and unmet needs for family planning. All these indicators have shown improvements, but developing countries are still far behind the target in sustainable development and reproductive health including maternal death. ${ }^{12}$

Sustainable Development Goals have been defined as development that meets the needs of the present without compromising the ability of the future generation to meet their own needs. ${ }^{13}$ These are efforts toward developing rational and responsible attitudes and behaviors in facing situations and are targeted mainly toward the students, who will form well-informed citizens of tomorrow. ${ }^{14}$

From the perspective of population explosion, the focus should be centered on reproductive rights. Reproductive rights, in its true sense, is when women have control on their bodies and reproductive health. It is a fact that education and economic security enable women to make judicious decisions. This freedom of 
making important decisions and choices will certainly reduce imposed and unwanted pregnancies. Once, David Allenborough from Independent UK highlighted that wherever women are put in control of their lives, both socially and politically, where medical facilities allow them to deal with birth control and where their husbands allow them to make decisions, birth rate falls. Women do not want to have 12 kids, out of which 9 will die.

\section{REFERENCES}

1. Malthusian Theory of Population. Available from: http:// www.cgge.aag.org.

2. International Conference on Population and Development. Available from: https:/ /en.m.wikipedia.org.

3. Women's Rights and Health-Population Matters. Available from: https://www.populationmatters.org.

4. Cook RJ, Fathalla MF. Advancing reproductive rights beyond Cairo and Beijing. Int Family Plann Perspect 1996;22(3):115-121.

5. World Fertility Report 2013. At the Extremes - the United Nations. Available from: www.un.org.
6. Mahantay A. Women empowerment: antidote to population explosion \& conducive to development. J Soc Sci 2002;6(1): 53-57.

7. Becker G. An economic analysis of fertility. Princeton, NJ: Princeton University Press. 1960.

8. Factors that influence population growth. Family Planning: $\mathrm{RMNCH}+\mathrm{A}$ in NHM Components. Available from: http:// nhm.gov.in/nrhm-components/rmnch-a/family-planning/ background.html.

9. NFHS-3. India 2005-2006. Mumbai: International Institute for Population Sciences.

10. Government of India 2015, Sample Registration Survey Status Report 2014. Office of the Registrar General and Census Commissioner, India. Ministry of Home Affairs.

11. Government of India. Family Welfare Statistics in India 2011. New Delhi: MOHFW.

12. WHO. Health in 2015 From MDG to SDG; 2015.

13. WHO. World Health Statistics 2016, Monitoring Health for the SDG; 2016.

14. UNESCO. Regional office for Education in Asia in 1979. Regional Workshop on Population \& Family Education. First Report Sept./Oct. 1970. Bangkok, Thailand. 